\title{
THE ROLE OF TELEMEDICINE AND DIGITALIZATION IN THE PARADIGM SHIFT OF MEDICAL SERVICES IN ROMANIA
}

\author{
Polixenia Aurora Roman (Pareșcura) \\ Bucharest University of Economic Studies, Marketing Faculty, Bucharest, Romania \\ polixeniaparescura@yahoo.com
}

\begin{abstract}
The article outlines the role of telemedicine within the entire medical services in Romania, and aims to highlight the benefits and limitations of this type of interaction, its current market size, its growth potential and the top ten private players involved. In order to achieve the goals set in the European Digital Strategy 2030, Romania must continue to adopt measures that include raising public awareness of the benefits involved by telemedicine, the support of large-scale projects that may test and evaluate telemedicine, as well as legislative acts to eliminate the barriers against the use of telemedicine. As digital medicine gains importance, several paradigms involving the doctor-patient interaction, prophylaxis, healthy human medicine, and the family doctors will also change. Both qualitative and quantitative data has been analysed in the research process. The former includes articles and surveys published by the specialist press. The quantitative data has been taken from reports published by the European Commission or by the World Health Organisation. With regard to the concept of „personalized medicine” and to the National Health Strategy 2021-2027, the author has consulted the State of Innovation 2020 report, elaborated by the Centre for Innovation in Medicine.
\end{abstract}

Keywords: healthcare, prevention, personalised medicine, telemedicine, ePatient, eHealth, healthy human medicine

JEL Classification: 111, I18, I30, M31, 033

Motto

"It has become increasingly clear that universal health coverage (UHC) cannot be achieved without the support of eHealth" (WHO, 2016)

\section{Introduction}

In the context of the coronavirus pandemic, the strengthening of prophylactic measures and the need to ensure public access to primary healthcare in general, and to telemedicine in particular, have sped up the implementation of new policies and public health programmes in many countries around the world. The Romanian authorities are to adopt the Operational Health Programme 2021-2027, which is considered to be the most ambitious and complex modernization programme of the health system. According to „Healthcare, a priority in the new policies 2021-2027", an event hosted last year by the Ministry of European Funds, an estimated 6 billion euro is due to be invested in healthcare (MIPE, 2020b).

Although Romania has been among the first countries in the world to use telemedicine in emergency medical interventions, the public health system has not fully exploited the potential of such practices. The private healthcare system has responded more promptly to the advantages of telemedicine, by launching an online platform as early as 2016 - such as Atlas, funded by Dr Mihai Bran (NN Asigurări, 2020) The turning point in the global development of telemedicine is represented by the sanitary crisis related to the COVID-19 pandemic. Telemedicine made more progress within one month than in the ten years before, with France at the forefront: early March 2020 there were 10k teleconsultations a day, and by the end of the month this number increased 100 times, reaching 1 million a day (EC, 2021: 11). These facts highlight one of the paradigm shift related to telemedicine: in over 
$70 \%$ of the typical primary healthcare services, the patient can interact with the doctor without being together in the same room.

\section{The healthcare of the future is based on prevention and on individual responsibility}

The Romanian national strategy for sustainable development 2030 , adopted by the Romanian Government in November 2018, stipulates that "the improvement of healthcare services and of the access to quality healthcare is essential for a sustainable patient- and prevention-centred society" (DpDD, 2018: 31).

Considering that healthcare services represent the most dynamic sector of the national economy (Gheorghe, 2018: 20), the strategy aims to achieve by 2030 "the full digitalization of the healthcare system and the elimination of paper documents in order to maximize the efficiency of medical interventions and to ensure the population's quick access to healthcare services" (DpDD, 2018: 35). The implementation of the three eHealth pillars - Big and Smart Data, Artificial Intelligence and the Internet of Things - will change the national healthcare system for ever (INOMED, 2020).

\section{Future of healthcare • The 4P Healthcare}

- Healthcare is participative: medical data is produced and monitored directly by the patient, assisted by an ever growing number of connected sensors. The doctor is no longer the sole source of medical information and as a result the patient-doctor relationship is transformed.

- preventive: the patients who periodically collect information regarding their health become ever more aware of the need to maintain good health, which paves the way towards prevention-based healthcare;

- personalized: the ongoing collection of private data - increasingly accurate and diverse - allows an increasingly personalized healthcare;

- predictive: technological progress, which enables the digitalization of every individual's complete genome, paves the way towards an increasingly predictive healthcare (CESE, 2017).

\section{Strengthening the co-producer patient's sense of responsibility}

The beneficiary has an active role in healthcare services, with a direct participation in every stage of the service delivery, as a co-producer (Purcărea, 2017: 95). The consumer's full involvement makes it possible to apply the preventive healthcare principles, as well as enables the implementation of personalized behaviour and treatment programmes. The patient's consent to private data processing represents the communication foundation within the eHealth system (CESE, 2017). It is up to the user to accept or decline eHealth services, as per article 5 in Annex 2 to the Government Resolution passed on 26th February 2021 (H.G.).

Placed at the centre of all marketing activities, the user imposes their place within the marketing mix. The e-patient will be periodically monitored and notified - especially through online and direct marketing channels - by the healthcare service suppliers. To increase its attractiveness, the marketing actions will be reinforced by publicity, public relations and promotions both within mobile applications and on social media pages. The reception of such messages depends however on the permissions granted within the initial contract with the supplier, as well as on the e-patient's level of interest (Gay, Charlesworth, Esen, 2009: 249).

\section{Increasing the personalization level in healthcare services}

In September 2017, the European Economic and Social Committee insisted on the challenge regarding an overburdening of the citizen with the responsibility of self-managing their health 
condition. The digital transformation, the access to knowledge and innovating personalized healthcare services may allow each e-patient to become an active participant in their own health maintenance, but also to contribute - as a collaborator, information producer and data supplier - to improving other citizens' health condition (CESE, 2017).

In a FutureProofing Healthcare report (2021) regardind to the European Personalized Health Care Index, Romania is located on the 32 nd position out of the 34 evaluated countries. The study analysed primarily the healthcare systems from within the EU and our country has to filling the gaps in 4 major fields: the knowledge training level in the healthcare system, the digital infrastructure, medical services and treatment access and digital technologies.

\section{The new multidimensional ecosystem of healthcare services}

Composed by the so-called „multiple stakeholders”, the healthcare ecosystem lies at the intersection point between the citizen, the medical and paramedical staff, on the one hand, and a multidimensional host of entities such as hospitals, health insurers, the pharmaceutical industry, big investors, regulating bodies and governments, on the other hand. In such a complex grid, healthcare marketing requires an integrated approach, connecting all the 3P actors - patients, payers, and prescribers - in a perspective that converges towards the entire population's health and welfare as a major goal (Purcărea, Hostiuc 2020: 92). The concept of an interest-based ecosystem convergence is underlined by lon Petroval, coordinator of EIT health center in Romania: "If technology is going to aid us all, as patients, doctors and administrators, the people funding, those establishing the rules, with the users and with the suppliers must reach an unanimous agreement" (CASPA, 2021).

\subsection{What is telemedicine?}

Telemedicine represents all distance healthcare services, delivered without the simultaneous, physical presence of the doctor and the patient, for diagnosing, treatment prescription, ailment monitoring or prevention purposes, in a secure way, by means of information technology and electronic communication (O.G.196, 2020) Telemedicine is very likely to become the healthcare of the future because it saves lives, is time-effective, substantially reduces the number of rehospitalizations and improves the citizens' welfare (Radu, 2017: 180).

\section{Main benefits of telemedicine}

One of the key benefits, with a great social impact, is related to the improved access to primary healthcare of all consumer categories. By eliminating the need for physical mobility, telemedicine can improve access to treatment in areas with a shortage of specialists or with difficult access to healthcare (FutureProofing Healthcare, 2021). According to the census on 30th September 2020, this also concerns the over 854.965 disabled people in this country (ANDPDCA). The second major benefit regards telemonitoring, which can improve the chronic disease patients' quality of life, thus reducing the number of hospitalizations (COM $689,2008)$. Another benefit concerns the facilitation of ongoing healthcare and of the access to healthcare services. According to the findings of a survey published early 2020 , based on over 10.000 respondents in 8 Romanian towns, $85 \%$ of the persons in need of healthcare assistance usually postpone the medical visit or cancel it altogether. This fact generates substantial health risks for millions of citizens, health-related work absences and a lower quality of life. It also directly affects employers' productivity and revenues, as many employees take time off work for reasons that might be avoided by an early medical check (Săndulescu, 2020).

Summing up, here are the advantages of telemedicine both for the healthcare system and for the medical services suppliers and beneficiaries (Radu, 2017: 178):

- telemedicine meets the requirements of personalized healthcare (INOMED, 2020) 
- the absence of direct contact helps prevent the spread of contagious diseases

- telemedicine offers geographical and demographic accessibility, eliminating the inequities of the public healthcare system

- it eases the burden on the medical staff in Emergency Units and frees resources to the entire public healthcare system, especially by providing secondary and tertiary medical assistance

- it reduces mortality through consultations in real time in extreme emergency situations

- using the Electronic Health Record, the doctor can access the patient's medical history quickly, obtaining both a general and a detailed view of their health condition

- it makes the diagnostic process faster and more accurate by facilitating communication within professional neworks - the doctors obtain "a second opinion" on a specific case

- it facilitates the citizens' access to "a second medical opinion" (Andriescu, 2021)

- it reduces the pressure on the social insurance system by lowering the number of hospitalization and re-hospitalization days

- it decreases the number of persons who refrain from a treatment due to lack of time to visit the practice (AMA Digital Accelator, 2021)

- it disciplines the activity of both prescribers and patients, by supporting the appointment flux, and ensuring that the disease is monitored and the treatment plan is respected (Medic Hub, 2021)

- it offers a sustainable alternative that spares time, energy, fuel, materials etc. (AMA Digital Accelerator, 2021)

- if supported by effective marketing, the telemedicine platforms may become channels to promote a healthy lifestyle, creating user communities that provide orientation to other consumers (Gay \& all, 2009: 396).

\section{Main barriers to telehealth adoption}

According to a PwC report for the European Commission, the main barriers to a large-scale adoption of telemedicine in the EU are the absence of a legislative framework for billing telemedicine services and the inadequate IT infrastructure, especially the lack of terminals required to access eHealth services, or connectivity problems (Fortune Business Insights, 2021). Further hindrances are related to the policies on the security, protection and processing of electronic medical records and of general health data.

\subsection{Objective rationale for adopting telemedicine}

It is of utmost priority to implement telemedicine as it addresses the limitations of the public healthcare system, considering Romania's rate of mortality, avoidable both by prevention and by treatment, among the highest in the European Union. Only four of the most significant deficiencies of the healthcare services in this country are listed bellow (OCDE, 2019):

- The public healthcare sector is underfunded - Romania's healthcare budget is among the lowest in the EU both per capita (1 029 EUR, compared to the EU average of 2884 EUR), and as a percentage of GDP (5\% compared to $9,8 \%$ in the EU)

- Prevention is not seen as a priority - investment in prevention lies under the EU average. In 2017, the budget for prevention represented only $1,8 \%$ of the overall health budget in Romania (the EU average is 3,2\%).

- Workforce shortage - the number of doctors and nurses is among the lowest in Europe

- The insufficient use of primary healthcare places a strain on hospital and emergency services.

\subsection{Catalyzing factors for telemedicine development in Romania}




\subsubsection{SARS-CoV-2 Pandemic}

Despite over 3.23 million victims worldwide $(\mathrm{WHO}, 2021)$ and being a global source of insecurity, the COVID-19 pandemic has given prominence to healthcare and to prophylactic measures. The need to fight the spread of the virus by physical distancing has accelerated the adoption of telemedicine, which is a considerably more suitable and safe way to advise and monitor individuals, whether for cases of light or chronic disease (AMA Digital Accelerator, 2021).

\subsubsection{The healthcare legislation review}

The COVID-19 pandemic has aggravated the sanitary crisis in Romania, pressing the authorities to adapt to the new realities and paving the way towards new, faster modalities to supply healthcare services (Presidency, 2020). The Romanian Government issued in November 2020 the Emergency Ordinance no. 196 supplementing Law no. 95/2006 regarding the healthcare reform (O.G., 2020). On 26th February 2021, it passed the Government Resolution which stipulated the six types of telemedical services accepted in Romania: tele-consultation, tele-expertise, tele-assistance, tele-radiology, tele-pathology și tele-monitoring (H.G., 2021).

\subsubsection{Rising digital literacy among the population}

The Digital 2021: Romania report confirms that, in January 2021, there were 15.49 million internet users. Last year, the number of social media users rising over the past year by 1 million $(+9,1 \%)$ and reaching 12 million persons, representing $62,6 \%$ of the total population. (see Figure 1)

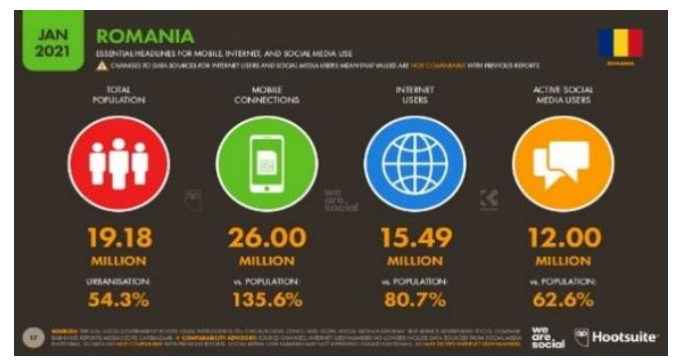

Figure 1. Digital 2021:Romania Report

Source: Datareportal, 2021

\subsubsection{Digital healthcare facilitates access to the second opinion}

In the current process of healthcare digitalization, the access to information acquires new significance, as the patient often wishes a second opinion on a certain medical condition. The rationale of any telemedicine application is the need to obtain quick access to a credible source of information, independent of territorial location or service fee (Andriescu, 2021).

\subsubsection{Telemedicine - appreciated by doctors and reimbursed by insurers}

The Emergency Ordinance no.196 (2020) confirms the validity of tele-consultation and includes it on the list of activities that can be reimbursed by public or private sanitary units, whether or not they have a contractual relation with the Health Insurance Agencies. As a legislative measure that had long been due, the ordinance was welcomed very warmly by the medical staff on all levels. In Alina Neagu's article (2020), Dr. Sandra Alexiu, President of Family doctors Association Bucharest-Ilfov, highlights an extremely dramatic aspect: "In the past fifteen years, [...] we have not been allowed to be doctors. Instead of treating our patients, we have had to issue numberless reference notes and letters." Ion Gheorghe 
Petrovai, a doctor and co-founder of FreshBlood HealthTech, states that "up to $70 \%$ of medical interactions can be carried out by distance" (Neagu, 2020).

\section{Telemedicine and healthcare digitalization in Romania}

The healthcare digitalization is the sixth priority pillar of the Operational Health Programme (OHP) 2021-2027, with three major objectives: the re-design and modernization of the National Healthcare Insurance Agency's (NHIA) IT system, the development of the National Monitor for healthcare data and the internal and external digitalization of healthcare institutions, as well as the fluidization of information streams. The funds allocated to digitalization through the OHP 2021-2027 amount to 260 million euro (MIPE, 2020a).

\subsection{The Electronic Health Record • the foundation in digitalizing healthcare services in Romania}

Romania must respond to an ambitious challenge set by the Digital Strategy 2030. In its meeting on 9th March this year, the European Commission proposed a Compass for the digital dimension that might reflect its digital objectives. Referring to public services, point 4 stipulates that, by 2030, any European citizen should be able to access their own Electronic Health Record (CE, 2021).

Funded by an investment of about 18,5 million euro from the European Social Fund for Regional Development in 2014, the project "An integrated IT system for the Electronic Health Record" began to be implemented. According to the data provided by NHIA, the EHR includes the following sections (CNAS-DES, 2014):

- Summary of essential vital medical data - accessible in emergency situations

- Complete medical history - an overview of the general health condition

- Antecedents declared to the doctor by the patient during the consultation

- The archive of medical records stored chronologically

- Secure personal data that can be modified only by the patient.

\subsection{The telemedicine market in Romania}

According to doctor Ion Petrovai, almost $20 \%$ of the Romanian population turned to telemedicine (CASPA, 2021). KeysFin specialists estimate the value of healthcare services in Romania around 15 billion lei in 2020 (Voinea, 2021). The net result (profit minus net loss) of the private healthcare services suppliers rose by $30 \%$ from 2018 and was almost 37 times $(+3.570 \%)$ higher than in 2010 , reaching 2,6 billion lei in 2019 , due to the conditions that Romanian patients find in private hospitals: the service quality, the high-performing equipment and the quality of the consultation, treatment and intervention rooms, according to KeysFin (Voinea, 2021). Philip Choban, CEO of Telios Care, one of the main suppliers of telemedicine services for employees in Romania, points out that about 65-70 million consultations, references and prescriptions are carried out or issued yearly in the family doctors and specialist practices, both public and private (Roșu, 2021).

\section{Telemedicine in the public health system}

Romania features among the pioneers in telemedicine, considering that the current State Secretary, Raed Arafat, managed, in Târgu Mureș in 2003, to connect the ambulance paramedics with specialist doctors in hospitals (Alexa, 2014). If major telemedicine projects were managed by the Romanian authorities with foreign support between 2008 and 2018 the North-American finance agreement USTDA (MS, 2012) and the POSCCE 49472 project, on EU funding, covered the rural areas in the Tulcea, Galați and Brăila counties (MS, 2014) - the number of privately funded telemedicine applications has risen significantly in the past year. Following the digitalization process, hospitals in major cities have taken the e-Health 
approach. For example, in December 2018, the "Dr. Carol Davila" Central Military Emergency University Hospital became a member of the International Society for Telemedicine and eHealth (ISfTeH) in December 2018 (SUUMC).

\section{Speeding up the adoption of telemedicine in Romania}

Improving the population's digital literacy, the development of the telecommunications infrastructure - access to high-speed internet, number of mobile applications, etc - as well as the creation of legislation favourable contributes to new private operators emerging on the national telemedicine market (Telios Care, Atlas, Recomedica, Docbook, Medic Chat, Doclandia, Doxtar, Medicai etc) which offer concrete solutions to a system that has long been ailing. The viability of telemedicine and the high growth potential of the private healthcare market are also proved by the collaborations between investment funds, insurers or banks and the telemedicine platforms:

- Smart Impact Capital and Telios Care - a first joint investment by three of the largest angel investor networks in Romania, amounting to 200.000 dollars (Săndulescu, 2020)

- Cleverage Venture Capital and Medic Chat (Andriescu, 2021)

- Cleverage Venture Capital and Recomedica (Abrihan, 2021)

- Roka X investment fund and Medicai (Andriescu, 2020)

- Next Capital and DocBook (Profit, 2020)

- NN Asigurări and Atlas App - the campaign "Live from one day to the welfare!" (NN, 2020)

- Transilvania Bank and DataKlas eMedical (HTTS, 2020)

According to Raluca Radbata from ING Bank România, the polarization of the healthcare market reflects the growth potential of the private sector, taking into account the large difference between the numbers of those who use public healthcare services $(70 \%)$ and of those who prefer private medical services (Mihalache, 2020).

\subsection{HelloGreen - an innovative personalized healthcare concept}

HelloGreen is a personalized medical management application targeted at a responsible audience, as it involves both prevention and therapy. HelloGreen supports the healthy human medicine, namely individuals who want to maintain their healthy condition, but also the treatment of patients who want to have priority access to the best doctors and to personalized treatment plans that reduce the risks associated with their disease (Besmax, 2021). In a recent interview published by the Avantaje magazine (2021), Florin Hozoc, founder of Besmax and application author, points out an essential aspect that changes the perception of classical medicine: „HelloGreen sets out from the premise that you are wealthier if you are healthy." The second premise says that personalized healthcare can offer better, safer and more effective services, improving both life expectancy and quality of life.

HelloGreen offers an innovative telemedicine solution that represents a distance communication instrument in the doctor-patient relationship, ensuring a $360^{\circ}$ monitoring of the subscribers. The HelloGreen application is in the test phase and is due to be launched at the end of May 2021. Personalized healthcare services will be offered on a monthly subscription plan between 0 and 30 euro, with over 80 medical specialties.

\subsection{Top 10 local telemedicine operators}

The operators mentioned in Tabel 1 excel in specific parts of telemedicine. For example, Telios Care grants access to a second opinion in a maximum of 24 hours, with an average response time of 2 hours. The Doclandia infrastructure allows the simultaneous processing of 100000 videocall sessions. MedicAl digitises medical imaging in a cloud storage, where it stocks over 100.000 files (Niță, 2021). 
Table 1. Top 10 Romanian telemedicine operators

\begin{tabular}{|r|l|c|c|c|c|c|}
\hline $\begin{array}{c}\text { Nr } \\
\text { crt }\end{array}$ & Application name & $\begin{array}{c}\text { Launch } \\
\text { year }\end{array}$ & Founder & Doctors & $\begin{array}{c}\text { Subscribe } \\
\text { rs / } \\
\text { accounts }\end{array}$ & $\begin{array}{c}\text { Specialtie } \\
\text { s }\end{array}$ \\
\hline 1 & Atlas & 2016 & dr Mihai Bran & 1000 & 200000 & N/A \\
\hline 2 & Medic Chat & 2017 & dr Emilian Rădoi & 223 & 30000 & 40 \\
\hline 3 & Telios Care & 2018 & Philip Choban & N/A & 75000 & 21 \\
\hline 4 & Doxtar & 2019 & Catălin Chiș & 100 & 50000 & 40 \\
\hline 5 & Recomedica & 2019 & Eduard Cioroagă & 326 & 30000 & N/A \\
\hline 6 & loncierge Medical & 2019 & dr Wargha Enayati & N/A & N/A & N/A \\
\hline 7 & Medicentrum & 2019 & dr Horațiu loani & 300 & N/A & 49 \\
\hline 8 & Doclandia & 2020 & Matei Țiboc & 120 & N/A & N/A \\
\hline 9 & ArcadiaLine & 2020 & Dan Fiterman & 100 & N/A & 40 \\
\hline 10 & MedicAl & 2020 & Mircea Popa & 1300 & 100000 & N/A \\
\hline
\end{tabular}

Source: author's research

\section{In conclusion}

In order that telemedicine achieves the success it is imperative that all actors involved adapt to the new digital context in the healthcare services provision (COM 689, 2008). The healthcare digitalization generates several paradigm changes, one of which associated with telemedicine: in $70 \%$ of the cases, the client no longer travels to the medical practice for the face-to-face consultation. Market research carried out in the United States in 2016-2019 reveals the fact that about $67 \%$ of the doctors prefer telemedicine for the efficiency of teleconsultations (AMA, 2020). The second paradigm change regards the new position of the family doctor. Within primary healthcare, the family doctor becomes the manager of a cross-disciplinary team. The new digital realities require the healthcare service beneficiary to become an active co-producer of their own health condition. Personalized healthcare involves two further paradigm changes related to a new e-patient conduct, namely the transition from ill patient medicine to the healthy human medicine. In relation to the classical "one size fits all" approach, personalized healthcare undertakes to provide right patient with the right prevention and treatment, at the right time and from the first moment.

This aspect was highlighted by Prof. Nick Guldemond at the fifth Personalized Medicine Conference, organized online in September 2020, in Bucharest: „A paradigm change is needed towards healthcare centred on the person. The patient will be seen as a partner in the effort of maintaining or improving their quality of life by means of a personalized treatment plan. It will require an integration and co-operation between services and a change in the roles and responsibilities of the decision-makers in the system. It is simple on a conceptual level, but difficult to implement systematically" (Voinea, 2020).

\section{References}

1. Abrihan, R. (2021) Startupul health-tech Medic Chat vizează o investiție de 250.000 de euro pe Seedblink [Online] Available from: https://bit.ly/3ebOde1 [Accesed 17 $17^{\text {th }}$ April 2021].

2. Alexa, A. (2014) Video-România este prima ţară din Europa, dacă nu şi din lume, în privinţa telemedicinei [Online] Available from: https://bit.ly/3t6LfOk [Accesed $10^{\text {th }}$ April 2021]. 
3. AMA-Digital Health Research (2020) Physicians' motivations and requirements for adopting digital health. Adoption and attitudinal shifts from 2016 to 2019 [Online] Available from: https://bit.ly/2RyoEMM [Accesed $10^{\text {th }}$ April 2021].

4. AMA Digital Accellerator (2021) Revoluția digitală în serviciile medicale: Aplicații eHealth și cazuri de utilizare [Online] Available from: https://bit.ly/3tyYo2N Accesat la [Accesed 17 $7^{\text {th }}$ April 2021].

5. Andriescu, V. (2019) Doxtar: consultații medicale plătite direct pe telefonul mobil în România [Online] Available from: https://bit.ly/32sBWMX [Accesed 17 th April 2021].

6. Andriescu, V. (2020) Startup-ul Medicai, tratamentul prin inteligență artificială pentru medicină [Online] Available from: https://bit.ly/32pDpDM [Accesed 17 th April 2021].

7. Andriescu, V. (2021) Platforma Medic Chat caută 250.000 de euro investiție pentru extindere [Online] Available from: https://bit.ly/33nA9JC [Accesed $5^{\text {th }}$ May 2021].

8. ANDPDCA (2020) Raport trimestrial al persoanelor cu dizabilități - septembrie 2020 [Online] disponibil la https://bit.ly/3dOBj5s [Accesed $8^{\text {th }}$ April 2021].

9. Avantaje (2021) Florin și Manuela Hozoc lansează cel mai spectaculos proiect românesc pe sănătate. [Online] Available from: https://bit.ly/2PHho0q [Accesed $7^{\text {th }}$ April 2021].

10. Besmax (2021) Aplicația HelloGreen. [Online] Available from: https://bit.ly/3dOpj4e [Accesed $7^{\text {th }}$ April 2021].

11. CASPA (2021) Dr. Ion-Gheorghe Petrovai, cofondator FreshBlood HealthTech: Telemedicina este o nouă cale de a face medicină [Online] Available from: https://bit.ly/3xNZCKd [Accesed $9^{\text {th }}$ April 2021].

12. CNAS-DES (2014). Dosarul electronic de sănătate - Informatii generale proiect [Online] Available from: https://bit.ly/2RmVO1D [Accesed 10 ${ }^{\text {th }}$ April 2021].

13. CNAS-Raport (2014). Raport de evaluare a impactului [Online] Available from: https://bit.ly/3dVWLFF [Accesed $8^{\text {th }}$ April 2021].

14. COM 689 (2008). Comunicatul Comisiei Comunităților Europene privind telemedicina și beneficiile sale pentru pacienți, pentru sistemele de sănătate și pentru societate [Online] Available from: https://bit.ly/3d1akVq [Accesed $5^{\text {th }}$ April 2021].

15. Comitetul Economic şi Social European - CESE (2017) Impactul revoluției digitale în domeniul asistenței medicale asupra asigurărilor de sănătate. [Online] Available from: https://bit.ly/3cXw4RZ. [Accesed $7^{\text {th }}$ April 2021].

16. Datareportal (2021) Digital 2021: Romania [Online] Available from: https://bit.ly/3d6tFo4 [Accesed $5^{\text {th }}$ April 2021].

17. DpDD - Departamentul pentru Dezvoltare Durabilă (2018). Strategia națională pentru dezvoltarea durabilă a României 2030. Bucharest: Paideia Publishing.

18. EC - European Commission (2021) 2030 Digital Compass: the European way for the Digital Decade [Online] Available from: https://bit.ly/3t6hblH [Accesed $8^{\text {th }}$ April 2021].

19. Fortune Business Insights (2021). Telemedicine-Market Research Report [Online] Available from: https://bit.ly/3tHGz1a [Accesed 17 th April 2021].

20. FutureProofing Healthcare (2021) Indicele European de Medicină Personalizată [Online] Available from: https://bit.ly/2PRnNWY [Accesed $5^{\text {th }}$ May 2021].

21. H.G. (2021). Hotărâre pentru aprobarea normelor metodologice de punere în aplicare a prevederilor art. I, punctul 1 din Ordonanţa de urgenţă a Guvernului nr. 196/2020 [Online] Available from: https://bit.ly/3mEF6qb la [Accesed $9^{\text {th }}$ April 2021].

22. Gay, R., Charlesworth, A., Esen, R. (2009) Marketing on-line. Bucharest: All Publishing.

23. Gheorghe, C. M. (2018). Marketingul experiențial în serviciile de sănătate. Bucharest: Carol Davila University Press

24. HTTS (2020) Anunțăm cu mândrie parteneriatul cu Banca Transilvania! [Online] Available from: https://bit.ly/2RCNfzS [Accesed $17^{\text {th }}$ April 2021].

25. INOMED (2020) Raportul State of innovation 2020 [Online] Available from: https://bit.ly/3xQboUo [Accesed $5^{\text {th }}$ May 2021].

26. Medic Hub (2021) Dr. Ioana Vodă, medic ORL: În pandemie, ne-am informatizat complet [Online] Available from: https://bit.ly/3sMzKKI [Accesed 21 th April 2021].

27. Mihalache, G. (2020) Tehnologia merge mână în mână cu industria medicală. [Online] Available from: https://bit.ly/2QyusW6 [Accesed 18 ${ }^{\text {th }}$ April 2021].

28. MIPE-Ministerul Investitiilor si Fondurilor Europene (2020a) Sinteza Programului Operațional Sănătate 2021-2027 [Online] Available from: https://bit.ly/3eYiyxc [Accesed $5^{\text {th }}$ May 2021]. 
29. MIPE-Ministerul Investitiilor si Fondurilor Europene (2020b) Dezbaterea „Sănătatea, o prioritate în noile Programe 2021-2027" [Online] Available from: https://bit.ly/3eYkV34 [Accesed $6^{\text {th }}$ May 2021].

30. MS Ministerul Sănătății (2012) Dezvoltarea sistemului de telemedicină, cu sprijinul Agenţiei de Dezvoltare a Comerţului din Statele Unite ale Americii (USTDA). [Online] Available from: https://bit.ly/3d4sfdG [Accesed $9^{\text {th }}$ April 2021].

31. MS Ministerul Sănătății (2014) Proiectul POSCCE 49472 - Creşterea calităţii actului medical în zonele rurale [Online] Available from: https://bit.ly/2QcvmqO [Accesed $9^{\text {th }}$ April 2021].

32. NN Asigurări (2020) Parteneriat pentru sănătatea și starea de bine a românilor: NN şi platforma ATLAS lansează campania "Trăiește de azi pe bine!" [Online] Available from: https://bit.ly/2RG5p3H [Accesed 17 $7^{\text {th }}$ April 2021].

33. Neagu, A., (2020) Cum a transformat coronavirusul consultația la medic. Telemedicina, probabil cea mai mare schimbare post-pandemie din sistemul medical din România [Online] Available from: https://bit.ly/3wD7vBu [Accesed $8^{\text {th }}$ April 2021].

34. Niță I. (2021) Mircea Popa, fondator şi CEO Medicai, platformă online pentru imagistică. Available from:https://bit.ly/2R49SNO [Accesed $8^{\text {th }}$ May 2021].

35. OCDE/European Observatory on Health Systems and Policies (2019). România - Profilul de țară din 2019 în ceea ce privește sănătatea [Online] Available from: https://bit.ly/3sc4MeW [Accesed $10^{\text {th }}$ April 2021].

36. O.G. 196 (2020) Ordonanță de urgență nr.196 din 18 noiembrie 2020 [Online] Available from: https://bit.ly/3uuEia4 [Accesed $8^{\text {th }}$ April 2021].

37. Presidency (2020) Reforma este principalul atribut sub auspiciile căruia trebuie conturat sistemul de sănătate românesc. [Online] Available from: https://bit.ly/3t6VGBv [Accesed $10^{\text {th }}$ April 2021].

38. Profit.ro (2020) Docbook, prima aplicație din România pentru programări online la doctor, primeste o investiție de 600.000 euro și dezvoltă o platfomă de Telemedicină [Online] Available from: https://bit.ly/3aozQBU [Accesed 16 ${ }^{\text {th }}$ April 2021].

39. Purcărea, V. L. at all. (2017) Marketingul îngrijirilor de sănătate: curs universitar. Bucharest: Carol Davila University Press

40. Purcărea, V. L., Hostiuc, M. (2020) Impactul mesajului publicitar asupra pacientului in comunicarea de Marketing. Bucharest: Carol Davila University Press

41. Radu, A. V. (2017) Marketingul online în serviciile de sănătate. Bucharest: Carol Davila University Press

42. Rădulescu, V. (2008) Marketingul serviciilor de sănătate. Bucharest: Uranus

43. Roșu R., 2021. Piaţa de telemedicină a crescut puternic în 2020. [Online] Available from: https://bit.ly/3ahOlYk [Accesed $17^{\text {th }}$ April 2021].

44. Săndulescu, L. (2020) Investiție de 200.000 de dolari într-un serviciu de telemedicină din România [Online] Available from: https://bit.ly/3ecuScD [Accesed 17 $7^{\text {th }}$ April 2021].

45. SUUMC (2018) Telemedicina, medicina viitorului [Online] Available from: https://bit.ly/3g0289E [Accesed $9^{\text {th }}$ April 2021].

46. Voinea, A. (2020) \#BiotechWeek2020. Prof. Nick Guldemond, despre sustenabilitatea sistemelor de sănătate: „Este nevoie de o schimbare de paradigmă către îngrijirea centrată pe persoană” [Online] Available from: https://bit.ly/3vDhnty [Accesed $5^{\text {th }}$ May 2021].

47. Voinea, A. (2021) O piață de miliarde: serviciile medicale private, la maxim istoric [Online] Available from: https://bit.ly/3sv0saS Accesat la 17 aprilie 2021.

48. WHO (2009) Telemedicine: opportunities and developments in Member States: report on the second global survey on eHealth [Online] Available from: https://bit.ly/32ctxNi [Accesed $8^{\text {th }}$ April 2021].

49. WHO (2021) Coronavirus Dashboard [Online] Available from: https://covid19.who.int/ [Accesed $9^{\text {th }}$ April 2021]. 